\title{
Neurotrophic Factors and Amyotrophic Lateral Sclerosis
}

\author{
Eva Ekestern \\ Department of Neuroimmunology, Brain Research Institute, University of Vienna, Austria
}

\section{Key Words}

Amyotrophic lateral sclerosis - Neurotrophic factor . Motor neuron - Clinical trial

\begin{abstract}
The cause of motor neuron death in amyotrophic lateral sclerosis (ALS) remains a mystery. Initial implications of neurotrophic factor impairment involved in disease progression causing selective motor neuron death were brought forward in the late 1980s. These implications were based on several in vitro studies of motor neuron cultures in which a near to complete rescue of axotomized neonatal motor neurons in the presence of supplementary neurotrophic factors were revealed. These findings pawed the way for extensive investigations in experimental animal models of ALS. Neurotrophic factor administration in rodent ALS models demonstrated a remarkable effect on survival of degenerating motor neurons and rescue of axotomized motor neurons, both in vivo and in vitro. In the absence of efficient therapy for ALS, some of these promising neurotrophic factors have been administered to groups of ALS patients, as they appeared available for clinical trials. Up to date, none of tested factors has lived up to expectations, altering the outcome of the disease. This review summarizes current findings on neurotrophic factor expression in ALS tissue
\end{abstract}

\section{KARGER}

Fax +41613061234

E-Mail karger@karger.ch

www. karger.com

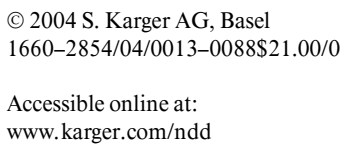

and these factors' potential/debatable clinical relevance to ALS and the treatment of ALS. It also discusses possible interventions improving clinical trial design to obtain efficacy of neurotrophic factor treatment in patients suffering from ALS.

Copyright $@ 2004$ S. Karger AG, Basel

\section{Introduction}

With a yearly incidence of 1-2 cases in 100,000 and a prevalence of approximately 4-9 in 100,000 individuals, amyotrophic lateral sclerosis (ALS) is the most common motor neuron disease in adults [1-3]. The hallmark of this devastating neurodegenerative disorder is a preferential loss of upper motor neurons of the motor cortex and lower motor neurons of the brain stem and the spinal cord, leading to muscle deterioration, paralysis and ultimately death. No curative treatment is available for this rapidly progressing disease and the life expectancy of ALS patients after diagnosis is usually only $1-5$ years. The etiology behind sporadic ALS is to date not known. Impaired neurotrophic factor production, release, and/or uptake however have been proposed as direct or indirect cause for the motor neuron loss observed in ALS. This proposal originated from several studies, demonstrating apparent neuroprotective effects after administration of tro-
Eva Ekestern, $\mathrm{PhD}$

Department of Neuroimmunology

Brain Research Institute, University of Vienna

Spitalgasse 4, AT-1090 Vienna (Austria)

Tel. +43 1427762823 , Fax +43142 779628, E-Mail office@ekestern.at 
phic factors to rodent motor neurons under various in vitro and in vivo conditions [4-8]. These initial findings prompted extensive investigations on neurotrophic factor interaction in neuronal cell culture systems and in experimental animal models of ALS. Moreover, large-scale clinical trials applying these factors on groups of ALS patients were quickly initiated. Despite the enormous success neurotrophic factors demonstrated in rescuing motor neurons both in experimental animal models and in neuronal and organotypic cell cultures, only debatable therapeutic efficacy has been detected after administrating neurotrophic factors to patients suffering from ALS. These discouraging results of attempts at treating ALS are however not very surprising as our knowledge concerning optimal administration, transportation, uptake, half-life and therapeutic levels of neurotrophic factors in man is limited. The above-mentioned neuroprotective effects of exogenously administrated neurotrophic factors observed in cell cultures and in animal models of ALS, either relied on (a) measurements performed under standardized conditions (very different from the condition complexity of humans), (b) a primary shortage of neurotrophic factor(s), or (c) on primary motor neuron damage different from what is observed in patients with sporadic ALS. Excessive administration of exogenous trophic support to an organism that shows no obvious shortage of neurotrophic factors could potentially be harmful [9]. Neurotrophic factors' ability to protect motor neurons has been reported to be dose-dependent $[10,11]$. This protective effect declines once the optimal concentration of administrated trophic factor is exceeded. So far, no studies revealing a clear-cut impaired synthesis or decreased levels of neurotrophic factors and/or their corresponding receptors in tissue from patients living with ALS have been published. Instead, performed studies have reported on unaltered or increased levels of neurotrophic factors in spinal cord, muscle, brain, skin, cerebrospinal fluid (CSF) and serum from patients with ALS [12-19]. In addition, there is no clear evidence of a primary deficiency of neurotrophic factors causing ALS. Hitherto, molecular mechanisms behind neurotrophic factor activity, mode of action and their possible influence in selective motor neuron degeneration remain poorly understood.

This review summarizes current findings on neurotrophic factor expression in different tissues from ALS patients, motor neuron protection by neurotrophic factors in ALS animal models and in vitro cultures and these factors potential/debatable clinical relevance to ALS and the treatment of ALS.

Neurotrophic Factors and Amyotrophic

Lateral Sclerosis

\section{Selective Motor Neuron Susceptibility and Trophic Support}

ALS is primarily a disease affecting the motor neuron system. Susceptible neuronal populations in ALS are the upper and lower motor neurons, transmitting cortical signals to the peripheral muscles. These vulnerable sets of cells dying in ALS are generated in excess during embryonic development. Their initial survival depends on their own ability to make contact with their target tissue (the muscle) to avoid undergoing prenatal physiological motor neuron cell death [20-22]. This target-derived neuron-muscle contact and subsequent neuronal survival is guided and regulated by secreted neurotrophic factors [23]. Despite the prerequisite of neurotrophic factor guidance for the development and survival of motor neurons, studies in mice have demonstrated a normal motor neuron development and survival in the absence of certain neurotrophic factors [24-28]. Based on these studies relying on single gene mutants, the ensuing unaffected motor neuron development could be explained by pleiotrophy and redundancy found among these neurotrophic factors [29-31]. However, certain neurotrophic factors are only readily expressed postnatal, indicating a regulatory and supportive function of these factors on motor neurons in adults [29, 32, 33]. Indeed, studies have shown that motor neuron depend on trophic support throughout life [34]. Because a selective motor neuron death is observed in ALS, a crucial question that remains to be countered is whether alterations in levels of neurotrophic factor accessible to the motor neurons precedes the onset of the disease or whether it is an unspecific response to present motor neuron damage.

\section{Neurotrophic Factors, Related Proteins and Growth Factors}

Neurotrophic factors are endogenous signaling proteins, promoting survival and well-being of specific populations of neurons as well as stimulating neuronal population differentiation. The neurotrophic factors are generally divided into three subgroups: neurotrophins, the glial cell-line-derived neurotrophic factor (GDNF) receptor ligands, and the neuropoietic cytokines. There is a continuously increasing number of neurotrophic factors being considered for clinical trials in ALS after demonstrating motor neuron protection in experimental models of ALS. Neurotrophic factors and related proteins which have revealed an ability to protect motor neurons are: ciliary

Neurodegenerative Dis 2004;1:88-100 
Table 1. Motor neuron enhancing neurotrophic factors and related proteins and their corresponding receptors

\begin{tabular}{lll}
\hline Classification & Factor & Receptor(s) \\
\hline Neurotrophin family & BDNF & trk B, p75 7 NTR \\
& NT-3 & trk C, trk A, trk B, p75 \\
& NT-4/5 & trk B, trk C, p75 \\
Neuropoietic & CNTF & CNTF-R $\alpha$, LIF rb, gp130 \\
\multicolumn{1}{c}{ cytokines } & LIF & LIF rb, gp130 \\
& CT-1 & LIF rb, gp130 \\
& IL-6 & IL-6-R, gp130 \\
GDNF family and & GDNF & GFR- $\alpha 1$, GFR- $\alpha$ 2, GFR- $\alpha 3$, RET \\
related proteins & NRTN & GFR- $\alpha 1$, GFR- $\alpha 2$, RET \\
IGF family & IGF-1 & IGF-R1 \\
FGF family & FGF & FGF-R \\
Scatter factor & HGF & c-met \\
Serphin family & PEDF & PEDF-R(s) \\
VEGF family & VEGF & VEGF-R1, VEGF-R2 \\
\hline
\end{tabular}

neurotrophic factor [5], neurotrophin-3 [7], neurotrophin$4 / 5$ [7], brain-derived neurotrophic factor [8], insulin-like growth factor [35], fibroblast growth factor [36], hepatocyte growth factor [37], interleukin-6 [38], leukemia inhibitory factor [39], cardiotrophin-1 [40], GDNF [6], neurturin [41], pigment epithelium-derived factor [42] and vascular endothelial growth factor [43]. Neurotrophic factors, related proteins, and growth factors with motor neuron potentiation and their corresponding receptors are listed in table 1.

\section{Neurotrophic Factor Production, Release, and Transport}

Neurotrophic factors are constitutively produced and are considered paracrine, endocrine or autocrine. Paracrine neurotrophic support could potentially include secretion from neighboring cells such as glial cells, Schwann cells or capillary endothelial cells, muscle fibers, shortaxon afferent neurons (excitatory and inhibitory interneurons and parasegmental neurons) and long-axon afferent neurons (suprasegmental neurons and dorsal root ganglia neurons) [44]. Endocrine trophic support, on the other hand, relies on delivery from distant cells, such as ependymal cells, via blood or CSF [45]. Autocrine support refers to motor neurons own ability to supply neurotrophic factors. Several studies have demonstrated target-derived retrograde transport of these factors from the periphery (muscle) to the spinal cord and the ventral horn motor neurons in particular $[6,8,46-48]$. Anterograde transport from the upper motor neurons to the lower motor neurons has also been reported $[46,49,50]$. The above-mentioned different modes and sites of action neurotrophic factors are thought to exert their trophic support through are outlined in figure 1.

The muscle fiber constitutes the single final target tissue for motor neuron signaling. Moreover, the neurodegeneration observed in ALS is highly selective, primary affecting motor neurons. It is tempting to propose an imbalance in neurotrophic factor production or release in muscle tissue, secondarily altering the accessibility of trophic support for the motor neurons at the motor neuron terminals. This hypothesis implicates a primary deficiency within the muscle resulting in selective damage to motor neurons. Generally, it has been postulated that failure of muscle, glial and/or Schwann cells to release sufficient amounts of neurotrophic factors that maintain and enhance the well-being of lower motor neurons might lead to a loss of this specific cell population. Lower motor neuron degeneration would in turn, according to this hypothesis, deprive the upper motor neuron cells of target released and retrograde transported neurotrophic factors. Several recent studies have demonstrated alterations in the levels of neurotrophic factor expression in ALS muscle tissue $[13,17,19]$. Interestingly, these studies reported on increased levels of trophic factors, rather suggesting motor neuron damage as a result of excessive neurotrophic support instead of a general shortage. Additionally, available neurotrophic factor receptor studies in ALS tissue, confirm a spared and intact receptor signaling capacity in this disease [14, 51-54]. These findings imply an intact retrograde transport of neurotrophic factors from the muscle to the motor neurons in the ventral spinal cord. Excessive levels of neurotrophic factors in muscle tissue would consequently lead to excessive neurotrophic factor levels in motor neurons. Measurement of GDNF in both affected and unaffected muscle tissue from an ALS patient revealed increased GDNF levels in affected muscle but levels comparable to control case tissue in unaffected tissue [13]. As there is no evidence of an alteration in neurotrophic factor levels prior to symptom onset, increased levels of neurotrophic factors in affected tissue in ALS patients might represent an unspecific secondary event. As neurotrophic factors are also produced by and released from glial cells, the increased levels of neurotrophic factors observed locally in the CSF could be a secondary event due to gliosis, which has been shown to occur both in ALS brain [55] and spinal cord [56]. Both astrocyte [57] and microglial cell [58] counts are increased
90

Neurodegenerative Dis 2004;1:88-100
Ekestern 


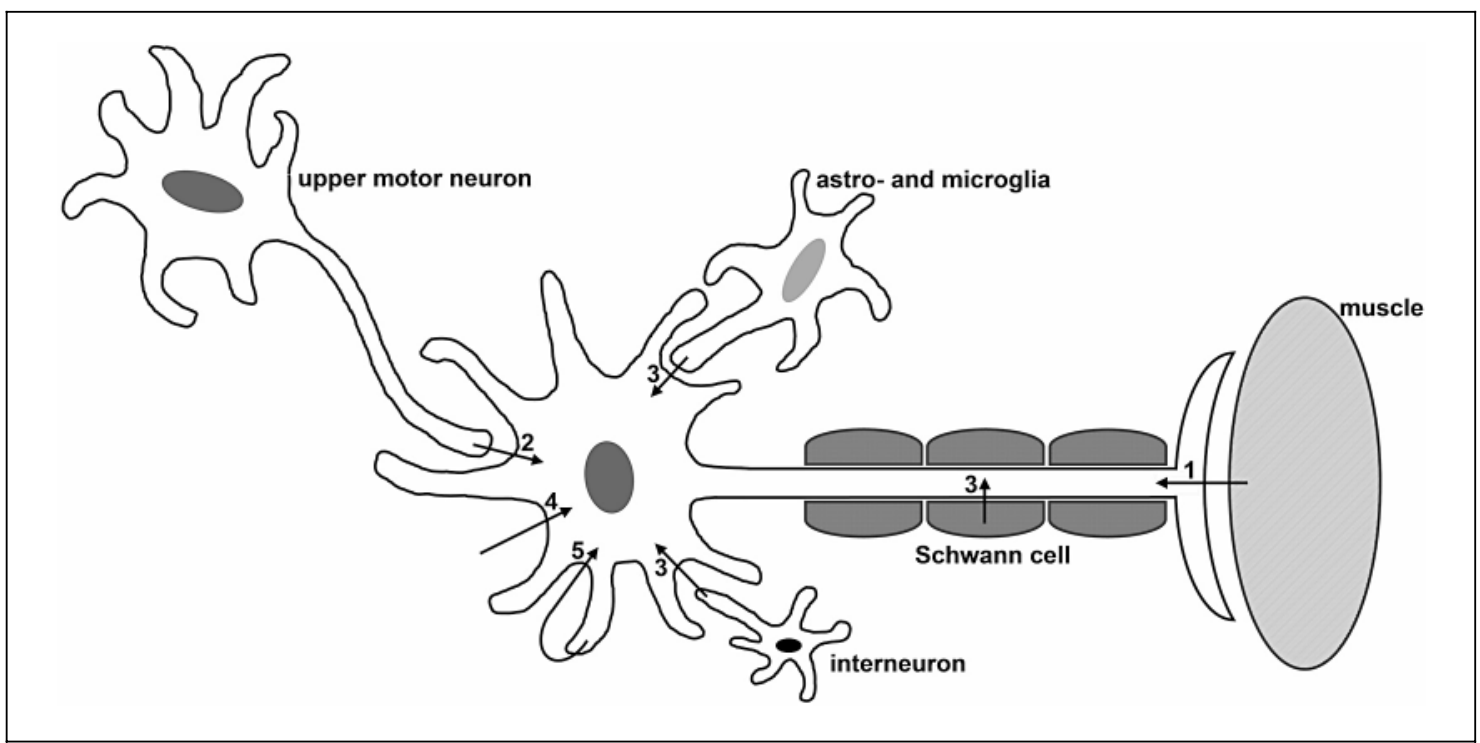

Fig. 1. Different mechanisms of neurotrophic support to a lower motor neuron: (1) retrograde transport (from muscle tissue), (2) anterograde transport (from upper motor neurons or other neurons), (3) paracrine support (from neighboring cells, i.e. microglia, astroglia, interneuron, Schwann cells), (4) endocrine support (from ependymal cells in the periphery, and (5) autocrine support (from the lower motor neuron itself).

in ALS spinal cord. Activated astrocytes [59-61] and microglia [62] have the capacity to produce and release increased amounts of trophic agents into the surrounding tissue. This glial activation can be either protective or cause destruction to the surrounding tissue. Interestingly, initial activation of astrocytes and microglia $[63,64]$ coincide with the onset of clinical disease in ALS mice models, suggesting that these cell types may play an important role in the neuronal degeneration process. In transgenic SOD1 mutant rat models, there is evidence of gliosis prior to symptom onset and occurrence of motor neuron death in the brain and spinal cord $[65,66]$.

\section{Neurotrophic Factor and Corresponding Receptors in ALS Studies}

\section{Neurotrophins}

\section{Nerve Growth Factor (NGF)}

NGF belongs to the family of neurotrophins and as the first isolated neurotrophin, it was initially described in the 1950s [67-69]. NGF has not been found to exert any specific neurotrophic effects on motor neurons in vivo or in vitro and hence has not been extensively investigated in relation to ALS. Performed studies of NGF's potential protective effect on motor neurons have turned out negative, either revealing no influence or a negative influence on the survival of motor neurons $[48,70]$. In spinal cord motor neuron areas from ALS patients, no specific expression of NGF or its corresponding high affinity receptor trk A have been detected [51]. Motor cortex from patients suffering from ALS have revealed decreased levels of NGF compared to control brains [71]. In a recent study, increased levels of NGF in postmortem muscle tissue from patients with ALS was observed [16].

\section{Brain-Derived Neurotrophic Factor (BDNF)}

$\mathrm{BDNF}$ was the second member of the neurotrophin family to be discovered, and was initially isolated from pig brain [72]. BDNF has been shown to promote survival of developing neurons [7,73] and has been reported to rescue developing $[8,74-76]$ and adult [77] motor neurons from axotomy-induced or naturally occurring cell death [78]. Recently, Kawamoto et al. [79] performed a study localizing BDNF in ALS spinal cord sections. They observed immunoreactivity for the BDNF protein in remaining motor neurons in ALS at a similar magnitude as seen in control cases. Both protein and mRNA expression of BDNF's high affinity receptor trk B, have been shown to be elevated in ALS spinal cord [54]. Investigations in both muscle biopsies and CSF samples from 
patients with ALS revealed unaltered levels compared to measurements in control tissue [12, 13, 17, 80]. These findings suggest BDNF not to play an active part in the motor neuron degeneration observed in ALS. This conclusion is further supported by clinical trials, in which subcutaneous BDNF administration to ALS patients generally did not alter the outcome of the disease [81]. One subgroup (patients with early respiratory impairment) benefiting from the BDNF administration was however found and this finding initiated further clinical trials with highdose subcutaneous administration or intrathecal administration of BDNF [82]. In the latter study, 25 ALS patients were infused with BDNF for 12 weeks in a sequential dose-escalating manner, using an implanted pump. Due to the small number of patients engaged and the study design no conclusions regarding the efficacy of the treatment could be drawn. No major adverse effects after administration of BDNF were however reported [83].

\section{Neurotrophin 3 (NT-3)}

The neurotrophin family member which is most abundantly expressed skeletal muscle, NT-3, has also been reported to have an impact on developing motor neurons [7]. NT-3 is expressed in developing motor neurons [84] and has been shown to act as a potent survival factor for upper motor neurons [85]. In postmortem ALS brain material, Duberley et al. [86] did not detect any difference in the number or intensity of neurons immunostained for NT-3 compared to control brain tissue. Another study from Duberley et al. [87] revealed a decreased NT-3 expression and unaltered trk C expression in ALS spinal cord tissue in comparison to equivalent control tissue. A recent study in postmortem ALS muscle tissue showed increased NT-3 expression, both at the mRNA and protein level [16].

\section{Neurotrophin-4/5 (NT-4/5)}

NT-4/5 was initially isolated from Xenopus laevis and was shown to reveal functional similarities with BDNF [88]. NT-4/5 also shares the high affinity receptor, trk B, with BDNF. NT-4/5 promotes survival of [73] and enhances acetyltransferase activity [7] in cultured rat motor neurons. NT-4/5 has not been extensively investigated in tissues from patients with ALS. A recent study however reported on increased mRNA levels of NT-4/5 in muscle tissue from ALS patients. This increase was enhanced during disease progression [16]. The number and intensity of NT-4/5 immunostained ALS cortical neurons in brain sections were unaltered when compared to control brain tissue [86].

\section{Neuropoietic Cytokines}

\section{Ciliary Neurotrophic Factor (CNTF)}

$\mathrm{CNTF}$ is a cytoplasmic protein belonging to the cytokine family. It was the first growth factor discovered to promote survival of lower motor neurons [4] and has demonstrated efficacy in rescuing a variety of experimental animal models presenting motor neuron degeneration [4, 89-92]. CNTF was also the first neurotrophic factor to be administered in clinical trials for ALS patients $[9,93]$. Two large-scale clinical trials with subcutaneous CNTF administration in patients with ALS were conducted in the 1990s. No significant differences between the treatment groups and the placebo groups in either trial for any of the measured parameters or survival could be observed. Instead, dose-dependent undesired side effects such as febrile response were debilitating. Due to these adverse effects, CNTF is no longer being considered as a potential candidate drug in the treatment of ALS or other types of motor neuron diseases. Measurements of CNTF and its corresponding receptor, CNTFR- $\alpha$, in spinal cord and motor cortex from patients affected by ALS revealed no impairment but instead increased levels of CNTF and CNTFR- $\alpha$ were detected [94, 95]. Elevated levels of CNTF have also been measured in skin biopsies from patients with ALS [96].

\section{Leukemia Inhibitory Factor (LIF)}

LIF was initially described as a glycoprotein able to enforce differentiation of myeloid leukemic cells [97]. LIF was later shown to promote survival of rat embryonic motor neurons [98] and to rescue axotomized motor neurons from newborn rats [99]. Investigations of LIF expression in ALS tissue are scarce, but ALS skin biopsies express increased levels of LIF compared to skin biopsies taken from patients with other neurological diseases [100]. This increase in LIF expression observed correlates to disease progression.

\section{Cardiotrophin-1 (CT-1)}

CT-1 is a muscle-derived cytokine, which is highly expressed in embryonic skeletal muscle and secreted by myotubes. It promotes the survival of cultured embryonic mouse and rat motor neurons [101], protects axotomized neonatal motor neurons [40]. CT-1 deficiency in embryonic mice results in partial motor neuron loss [101]. Both motor neuron cultures and axotomized motor neurons benefit from exogenous CT-1 administration [40]. CT-1 has yet not been investigated in ALS tissue. 


\section{Interleukin-6 (IL-6)}

IL-6 is a cytokine usually derived from T cells. The factor can however be produced by other cells including astrocytes and microglial cells in the CNS. Conflicting results on levels of IL-6 in CSF from ALS patients have been reported. Sekizawa et al. [102] detected elevated IL-6 levels in ALS CSF, whereas Krieger et al. [103] did not find any significant difference when comparing the findings in ALS CSF and control CSF. Increased levels of IL-6 has also been observed in both serum and skin biopsies from ALS patients [104].

\section{GDNF Family of Related Proteins}

\section{$G D N F$}

GDNF, a distant member of the transforming growth factor- $\beta$ (TGF- $\beta$ ) super family, was originally isolated as a factor from glial cell conditioned medium that promotes the survival and phenotype of ventral dopaminergic neurons [6]. GDNF has demonstrated great potency in supporting motor neuron survival in experimental models [6, 105]. Compared to the neurotrophins, GDNF reveals a 100 -fold greater efficacy in rescuing spinal motor neurons [106]. In vivo, GDNF prevents programmed cell death and atrophy of motor neurons during axotomy-induced degeneration of motor neurons [47]. Increased levels of GDNF mRNA in postmortem spinal cord tissue [107] and GDNF protein in CSF [12] have been demonstrated in ALS patients in comparison to controls. Increased mRNA levels of GDNF expression has also been detected in muscle biopsies from patients with ALS $[6,13,19]$. Immunostaining for one of GDNF's receptors, the Ret receptor, showed persistent expression of the Ret protein in remaining motor neurons in ALS spinal cord as compared to control cases [52]. Mitsuma et al. [53] also reported on a preserved GDNF receptor expression in ALS spinal cord, in an investigation comprising both mRNA and protein levels of GFR a-1, the specific receptor for GDNF. Ret mRNA and protein were exclusively expressed in motor neurons, whereas GFR a-1 was expressed in both motor neurons and glial cells. A study carried out in muscle tissue from patients with ALS revealed an unaltered expression of GFR a-1 mRNA in comparison to controls [19]. The same group failed to detect Ret mRNA in muscle tissue from ALS patients and control cases.

\section{Immunoglobulin Factor (IGF) Family}

\section{$I G F-1$}

IGFs belong to a family of structurally and functionally related proteins that include insulin, IGF-1 and IGF-2. Several studies have implicated that particularly IGF-1, may exert trophic support for motor neurons, and consequently most of its clinical development has focused on the treatment of motor neuron diseases [82]. Immunoglobulin factor IGF-1 has been suggested to support motor neurons [108] in pre-clinical studies based on efficacy on motor neuron survival in vitro [35, 109]. Initial clinical trials administrating IGF-1 subcutaneously to patients affected with ALS revealed a slight slowed progression of the disease $[110,111]$. Larger trials however, failed to reproduce previous findings and no significant improvement in comparison to the placebo group was observed [112]. IGF-1 receptor immunoreactivity and levels of IGF-1 have been shown to either be unaltered $[113,114]$ or increased in ALS spinal cord [51, 113, 115] in comparison to control tissue analyses. These findings support the negative outcome of the clinical trials, where no benefit after administration of the factor was observed. Serum levels of IGF-1 among patients affected by ALS did not differ compared to serum levels of control cases [116].

\section{Fibroblast Growth Factor (FGF) Family}

\section{$F G F$}

FGF is a neurotrophic factor abundantly found in spinal cord and brain tissue in rat [117-119] and human [120]. FGF prevents death of spinal cord motor neurons in rats after experimental spinal cord injury [121, 122]. Interestingly, FGF has been detected in cholinergic motor neurons [117], which are affected in ALS. In fact, FGF has been localized to ventral horn cells in the spinal cord of ALS patients [114, 123]. Kage et al. [123] found decreased mRNA levels of FGF in spinal cord from ALS patients in comparison to controls. They also reported that $95.9 \%$ of cholinergic neurons in the ventral horn expressed FGF, at the same time as they detected a reduction in number of cholinergic neurons in the ventral horn spinal cord from patients with ALS. Another study reported on unaltered FGF receptor expression in ALS spinal cord compared to controls [114]. Recently, increased levels of FGF were detected both in CSF and serum from patients suffering from ALS in comparison to control cases [124]. 


\section{Scatter Factor}

\section{Hepatocyte Growth Factor (HGF)}

HGF is a secreted cytokine with neurotrophic activity $[125,126]$. HGF has been demonstrated to protect and support motor neurons $[37,127]$ and was recently shown to be moderately up-regulated in CSF from patients with ALS in comparison to control CSF [14]. The corresponding c-Met receptor was unaffected in this patient group, suggesting an unaltered signaling ability [14]. Kato et al. [128] reported on similar or increased signaling intensity of both HGF and c-Met in ALS spinal cord motor neurons compared to control cases and c-Met induction in ALS spinal cord.

\section{Serphin Family}

\section{Pigment Epithelium-Derived Factor (PEDF)}

PEDF, a recently defined trophic factor, is a glycoprotein belonging to the serine protease inhibitor (serphin) family. PEDF has been shown to exert neuroprotection of motor neurons $[42,129]$. Studies in ALS CSF revealed a significant elevation of this factor at the protein level in comparison both to CSF from other neurological patients and from patients with other neurodegenerative conditions [15] suggesting PEDF as a selective trophic factor for ALS.

\section{Vascular Endothelial Growth Factor (VEGF) Family}

\section{$V E G F$}

VEGF has long been recognized as a crucial factor in controlling the growth and permeability of blood vessels. It was recently hypothesized as a potential trophic factor for motor neurons. Oosthuyse et al. [43] discovered progressive motor neuron degeneration development in transgenic mice with a deletion in the hypoxia-response element of the Vegf promoter, ensuing in reduced hypoxic VEGF expression in the spinal cord of these mice. The pathogenesis of these transgenic mice is not fully understood but could in part be explained by a longstanding mild ischemia. This ischemia would result from a reduced neural vascular perfusion in these mice. In the same investigation, VEGF was also shown to protect rodent motor neurons in culture from cell death induced by serum withdrawal, hypoxia, or hypoglycemia. Further, VEGF was demonstrated to rescue motor neurons from axotomy-induced cell death in vitro, acting like a typical neurotrophic factor for this neuronal population [43]. VEGF has also been shown to be abundantly expressed in cultured spinal glial cells. No mutations in VEGF resulting in gene inactivation have been linked to human diseases so far. This is most likely due to the fact that the absence of even a single VEGF allele is embryonic lethal. Impaired hypoxic regulation of VEGF was recently shown to constitute a risk factor for ischemic heart disease, indicating that abnormal VEGF regulation, and not function, may predispose to pathological disorders. Recently, it was shown that a specific haplotype in the Vegf promoter sequence in a subgroup of ALS patients correlates with impaired VEGF plasma levels [130]. Attempts at measuring possible altered levels of VEGF in CSF from patients with ALS have so far been unsuccessful due to detection limitations in commercial ELISA kits [131]. Increased levels of VEGF have been reported in ALS serum in comparison to control serum. In the same study, VEGF levels in spinal cord from patients with ALS were shown to be unaltered compared to levels in control spinal cord tissue [18].

\section{SR57746A (Xaliproden)}

SR57746A, a small non-peptide compound, is thought to mimic neurotrophic factor activity or to exhibit neurotrophic activity through an induction of the natural biosynthesis of endogenous neurotrophic factors. The substance has revealed efficacy in mouse models of motor degeneration [132-134] and has also been administrated orally in a phase II clinical trial in treatment of ALS. The initial clinical trial reported a significant decrease in the rate of functional decline over the 8-month period administered but the two large-scale phase III follow-up trials, testing the compound administered over an 18-month period, were not able to reproduce the initial findings. Hence, SR57746A is no longer a candidate in the treatment attempts of ALS.

\section{Experimental Animal and in vitro Models of ALS}

Several experimental animal models of ALS have been presented over the past decades [for review, see 135]. Some of them develop spontaneous motor neuron degeneration due to genetic defects of autosomal recessive or dominant inheritance (i.e. pmn mouse, wobbler mouse, nmd mouse, mnd mouse and wasted mouse), while others rely on transgenic, knock out or deletion techniques (i.e. SOD1 mouse/rat, mice overexpressing neurofilament and 
vegf mouse). Several of these animal models have benefited from subcutaneous [38, 90, 90, 136-140], intramuscular [141-143] or intraperitoneal [144, 145] injections of different neurotrophic factors. These favorable effects observed in animal models have relied on in vivo read-out parameters such as grip strength and weight change observations but also on in vitro parameters such as estimation of axonal degeneration and neuronal loss. Slowed disease onset and/or progression have been observed after administration of BDNF [137, 143], CNTF [92], LIF [144] or GDNF $[142,146]$ to these animals. Several neuropoietic cytokines (CNTF, LIF, IL-6) have proven to protect motor neurons from axotomy-induced death in a neonatal murine motor neuron degeneration model [38].

The, at present, only available agent used for treatment of ALS, riluzole, is an anti-excitotoxic substance that has been demonstrated to stimulate the synthesis of BDNF and GDNF in cultured mouse astrocytes [147]. In vitro studies using organotypic spinal cord slice cultures or motor neuron cultures have also been performed. Corse et al. [10] tested the potential neuroprotective effect of neurotrophic factors in a rat organotypic spinal cord slice model of neurodegeneration caused by glutamate transport inhibition. Their data demonstrate protective effects using IGF-1, GDNF, and NT4/5, whereas BDNF, CNTF, and NT-3 could not prevent motor neuron death. In the same rat model, Bilak et al. [148] were later able to reveal a decreased motor neuron cell death after addition of GDNF and/or IGF-1. They also demonstrated an increased cell survival potentiation of GDNF when combining the treatment of GDNF with IGF-1. Such additive effects when applying more than one neurotrophic factor has been described in several reports [89, 91, 149]. This indicates that the regulation of motor neuron survival is a highly complex process that is influenced by more than one neurotrophic factor.

\section{Conclusion and Discussion}

Every attempt at treating ALS by application of neurotrophic factors has so far turned out a failure. Despite these discouraging therapy outcomes, several options on improvement of trophic factor therapy in ALS deserve to be further investigated.

\section{Pre-Clinical Testing}

Once shortage of neurotrophic factor(s) has been determined in relevant tissue from patients with ALS in comparison to control tissue, this neurotrophic factor might be considered for clinical trials. A reasonable initial approach could include pre-clinical testing by means of local (non-systemic) injections. Instead of rapidly setting off very expensive, time-consuming, large-scale multicenter trials, it might be worthwhile to test the efficacy of a neurotrophic factor on a small group of ALS patients. Injection of this factor directly to the site of normal secretion, at the motor endplate, by unilateral frequent (daily) local injection into one defined affected or unaffected peripheral muscle and use the opposite muscle for placebo injection could provide valuable information on the potential protective effect of the neurotrophic factor assigned to be tested in clinical trials. In vivo gel electroporation of GDNF into skeletal muscle of SOD1 mice has provided evidence of the feasibility of such an approach and the relative low cost [150].

\section{Optimizing Administration}

To date, very little attention has been devoted to optimizing the administration of neurotrophic factors in the treatment of ALS. Performed clinical trials have relied on oral, subcutaneous or intrathecal administration of applied neurotrophic factors. Many neurotrophic factors are locally produced in cells that are in direct contact with the motor neurons. Several studies have detected normal signaling ability for trophic factor receptors. Since the half-life of several available trophic factors is very short, systemic administration might not provide optimal trophic factor levels accessible to the motor neurons. Administration direct at the site of secretion might be one way to circumvent this predicament. Another way to obtain efficacy would be to allow the trophic factor passage through the blood-brain barrier. This requires the design of molecules of a size and hydrophobic character that will allow passage through the blood-brain barrier or the coupling of the neurotrophic factor to a transporter molecule that can pass the blood-brain barrier. Either technique will certainly provide a frame for future administration improvements. Albeck et al. [151] have presented a successful non-invasive transport system for GDNF using antibodies against transferring receptors in the blood-brain barrier. A recently developed technique relying on transduction of recombinant adeno-associated virus vectors [152] transporting and delivering factors from the site of injection in the muscle to the motor neuron somata in a retrograde fashion, has provided promising data when treating SOD1 mice with IGF-1 [153]. With this administration technique, not only animals receiving IGF-1 before disease onset presented an increased survival, but also animals that were provided initial treatment at time 
of symptom onset lived longer than untreated animals. At this point, neurotrophic factor delivery via adeno-associated virus vectors has not been fully evaluated with respect to longstanding tolerance and efficacy. Further studies addressing this concern needs to be undertaken and delivery to patients suffering from ALS will likely request additional refinement and modification of the system. Further development of small molecules, such as SR57746A, that either mimic or potentiate the expression and activity of naturally occurring neurotrophic factors might also be helpful for improved treatment of ALS. Clinical trials administrating neurotrophic factors need to be carefully monitored to assure a secure, rapid, and adequate uptake of applied trophic factor. If not, desired doses of active substance might never be achieved. Moreover, we need to reach a better understanding of the action of these neurotrophic factors outside the nervous system to limit potential and evident adverse effects to a minimum in correlation to increasing doses.

\section{Novel Neurotrophic Factors}

With a continuously growing list of trophic factors described, it is possible that the ultimate trophic factor(s) for motor neurons remains to be discovered. Other newly characterized members of the GDNF family of trophic factors, i.e. artemin [154], persephin [155], and neurturin [156] or related factors, might offer a more directed and specific support of motor neurons. None of these factors has appeared in the literature yet as tested positive as drugs for motor neuron rescue in ALS. Further, no studies have been brought forward, in which the levels of either of these factors have been measured in ALS tissue.

\section{Neurotrophic Factor Cocktail Treatment}

The most recent experiments in animal models of ALS focused on additive effects on motor neuron protection when treating the animals with a combination of different neurotrophic factors. Providing a cocktail of neurotrophic factors might turn out more effective in the treatment of patients suffering from ALS. This tempting approach however raises questions such as which neurotrophic factors to mix, what concentrations to use, and during which phases of the disease progression to distribute the different neurotrophic factors.

\section{Animal Models of ALS}

Bearing the above-mentioned reservations in mind, the initial optimism which neurotrophic factor treatment for ALS was given must be re-evaluated. An animal model strictly resembling ALS in its course, with upper and low- er motor neuron degeneration in adulthood, is mandatory if we want to draw decisive conclusions from neurotrophic factor studies in animals for improved treatment of ALS patients. Models where immature motor neurons are treated cannot fully be compared to the human condition. A comparative study in man and rat spinal cord tissue revealed extensive species difference which further points towards the difficulty in drawing conclusions from rodent models [114]. As long as we rely on present ALS animal models, it is first necessary to understand the underlying mechanisms, which provide neurotrophic factor protection in current models, before adapting the successful treatments to the human clinical syndrome. Moreover, many studies in ALS animal models demonstrating a clear neuroprotection are based on neurotrophic factor treatment initiated before symptom onset. At present, patients with ALS neither receive neurotrophic factor treatment prior to symptom onset, nor at symptom onset. Instead, most patients only receive treatment once diagnosis has been confirmed. The average time span between symptom onset and diagnosis, allowing the possibility of treatment initiation, is approximately 13 months [157].

As reviewed in the present article, no evidence of clear neurotrophic factor impairment in patients with ALS is available. Taken together, the above-listed findings suggest that motor neurons in ALS patients may receive sufficient neurotrophic factor supply and that there is no demand for further support of these factors from surrounding tissues. Available data instead point towards a possible toxic effect on motor neurons due to excessive levels of neurotrophic factors in this disease. It needs to be stressed that as long as we have not detected decreased mRNA or protein levels of any neurotrophic factor or down-regulation of corresponding receptors in ALS patients, the likelihood of success when applying these agents on patients suffering from ALS is small.

\section{Acknowledgement}

This work was supported by the Swedish Brain Foundation. 


\section{References}

1 Brown RH Jr, Robberecht W: Amyotrophic lateral sclerosis: Pathogenesis. Semin Neuro 2001;21:131-139.

$\checkmark 2$ Rowland LP, Shneider NA: Amyotrophic lateral sclerosis. N Engl J Med 2001;344:16881700 .

$\checkmark 3$ Shaw CE, Al Chalabi A, Leigh N: Progress in the pathogenesis of amyotrophic lateral sclerosis. Curr Neurol Neurosci Rep 2001;1:69-76.

$\checkmark 4$ Adler R, Landa KB, Manthorpe M, Varon S: Cholinergic neuronotrophic factors: Intraocular distribution of trophic activity for ciliary neurons. Science 1979;204:1434-1436.

$\checkmark 5$ Arakawa Y, Sendtner M, Thoenen H: Survival effect of ciliary neurotrophic factor on chick embryonic motoneurons in culture: Comparison with other neurotrophic factors and cytokines. J Neurosci 1990;10:3507-3515.

-6 Lin LF, Doherty DH, Lile JD, Bektesh S, Collins F: GDNF: A glial cell line-derived neurotrophic factor for midbrain dopaminergic neurons. Science 1993;260:1130-1132.

7 Wong V, Arriaga R, Ip NY, Lindsay RM: The neurotrophins BDNF, NT-3 and NT-4/5, but not NGF, up-regulate the cholinergic phenotype of developing motor neurons. Eur J Neurosci 1993;5:466-474.

-8 Yan Q, Elliott J, Snider WD: Brain-derived neurotrophic factor rescues spinal motor neurons from axotomy-induced cell death. Nature 1992;360:753-755.

$\checkmark 9$ Miller RG, Petajan JH, Bryan WW, Armon C, Barohn RJ, Goodpasture JC, Hoagland RJ, Parry GJ, Ross MA, Stromatt SC: A placebocontrolled trial of recombinant human ciliary neurotrophic (rhCNTF) factor in amyotrophic lateral sclerosis. rhCNTF ALS Study Group. Ann Neurol 1996;39:256-260.

-10 Corse AM, Bilak MM, Bilak SR, Lehar M, Rothstein JD, Kuncl RW: Preclinical testing of neuroprotective neurotrophic factors in a model of chronic motor neuron degeneration. Neurobiol Dis 1999;6:335-346.

$\checkmark 11$ Vejsada R, Tseng JL, Lindsay RM, Acheson A, Aebischer P, Kato AC: Synergistic but transient rescue effects of BDNF and GDNF on axotomized neonatal motoneurons. Neuroscience 1998;84:129-139.

12 Grundstrom E, Lindholm D, Johansson A, Blennow K, Askmark H: GDNF but not BDNF is increased in cerebrospinal fluid in amyotrophic lateral sclerosis. Neuroreport 2000;11: 1781-1783.

13 Grundstrom E, Askmark H, Lindeberg J, Nygren I, Ebendal T, Aquilonius SM: Increased expression of glial cell line-derived neurotrophic factor mRNA in muscle biopsies from patients with amyotrophic lateral sclerosis. J Neurol Sci 1999;162:169-173.

14 Kern MA, Friese M, Grundstrom E, Korhonen L, Wallin A, Aquilonius SM, Askmark H, Schirmacher P, Lindholm D: Amyotrophic lateral sclerosis: evidence for intact hepatocyte growth factor/met signalling axis. Cytokine 2001;15:315-319.
15 Kuncl RW, Bilak MM, Bilak SR, Corse AM, Royal W, Becerra SP: Pigment epitheliumderived factor is elevated in CSF of patients with amyotrophic lateral sclerosis. J Neurochem 2002;81:178-184.

16 Kust BM, Copray JC, Brouwer N, Troost D, Boddeke HW: Elevated levels of neurotrophins in human biceps brachii tissue of amyotrophic lateral sclerosis. Exp Neurol 2002;177:419_ 427

17 Lie DC, Weis J: GDNF expression is increased in denervated human skeletal muscle. Neurosci Lett 1998;250:87-90.

18 Nygren I, Larsson A, Johansson A, Askmark H: VEGF is increased in serum but not in spinal cord from patients with amyotrophic lateral sclerosis. Neuroreport 2002;13:2199-2201.

19 Yamamoto M, Mitsuma N, Inukai A, Ito Y, Li M, Mitsuma T, Sobue G: Expression of GDNF and GDNFR- $\alpha$ mRNAs in muscles of patients with motor neuron diseases. Neurochem Res 1999;24:785-790.

20 Hamburger V: The effects of wing bud extirpation on the development of the central nervous system in chick embryos. J Exp Zool 1934;68: 449-494.

21 Hamburger V: Regression versus peripheral control of differentiation in motor hyperplasia. Am J Anat 1958;102:365-410.

22 Oppenheim RW: Cell death during development of the nervous system. Annu Rev Neurosci 1991; 14:453-501.

23 Lewin GR, Barde YA: Physiology of the neurotrophins. Annu Rev Neurosci 1996;19:289317.

24 Conover JC, Erickson JT, Katz DM, Bianchi LM, Poueymirou WT, McClain J, Pan L, Helgren M, Ip NY, Boland P: Neuronal deficits, not involving motor neurons, in mice lacking BDNF and/or NT4. Nature 1995;375:235238.

25 Conover JC, Yancopoulos GD: Neurotrophin regulation of the developing nervous system: Analyses of knockout mice. Rev Neurosci 1997;8:13-27.

26 DeChiara TM, Vejsada R, Poueymirou WT, Acheson A, Suri C, Conover JC, Friedman B, McClain J, Pan L, Stahl N: Mice lacking the CNTF receptor, unlike mice lacking CNTF, exhibit profound motor neuron deficits at birth. Cell 1995;83:313-322.

27 Ernfors P, Lee KF, Jaenisch R: Mice lacking brain-derived neurotrophic factor develop with sensory deficits. Nature 1994;368:147-150.

28 Liu X, Ernfors P, Wu H, Jaenisch R: Sensory but not motor neuron deficits in mice lacking NT4 and BDNF. Nature 1995;375:238-241.

29 Lindsay RM, Wiegand SJ, Altar CA, DiStefano PS: Neurotrophic factors: from molecule to man. Trends Neurosci 1994;17:182-190.

30 Mitsumoto H, Tsuzaka K: Neurotrophic factors and neuromuscular disease. II. GDNF, other neurotrophic factors, and future directions. Muscle Nerve 1999;22:1000-1021.
31 Mitsumoto H, Tsuzaka K: Neurotrophic factors and neuromuscular disease. I. General comments, the neurotrophin family, and neuropoietic cytokines. Muscle Nerve 1999;22: 983-999.

32 Sendtner M: Neurotrophic factors; in Brown RH Jr, Meininger V, Swash M (eds): Amyotrophic Lateral Sclerosis. London, Dunitz, 2000, pp 289-308.

33 Stockli KA, Lillien LE, Naher-Noe M, Breitfeld G, Hughes RA, Raff MC, Thoenen H, Sendtner M: Regional distribution, developmental changes, and cellular localization of CNTFmRNA and protein in the rat brain. $\mathrm{J}$ Cell Biol 1991;115:447-459.

34 Lindsay RM: Therapeutic potential of the neurotrophins and neurotrophin-CNTF combinations in peripheral neuropathies and motor neuron diseases. Ciba Found Symp 1996;196: 39-48.

35 Ang LC, Bhaumick B, Munoz DG, Sass J, Juurlink BH: Effects of astrocytes, insulin and insulin-like growth factor I on the survival of motoneurons in vitro. J Neurol Sci 1992;109:168172.

36 Hughes RA, Sendtner M, Goldfarb M, Lindholm D, Thoenen H: Evidence that fibroblast growth factor 5 is a major muscle-derived survival factor for cultured spinal motoneurons. Neuron 1993;10:369-377.

37 Ebens A, Brose K, Leonardo ED, Hanson MG Jr, Bladt F, Birchmeier C, Barres BA, TessierLavigne M: Hepatocyte growth factor/scatter factor is an axonal chemoattractant and a neurotrophic factor for spinal motor neurons. Neuron 1996;17:1157-1172.

38 Ikeda K, Kinoshita M, Tagaya N, Shiojima T, Taga T, Yasukawa K, Suzuki H, Okano A: Coadministration of interleukin-6 (IL-6) and soluble IL-6 receptor delays progression of wobbler mouse motor neuron disease. Brain Res 1996;726:91-97.

39 Kurek JB, Radford AJ, Crump DE, Bower JJ, Feeney SJ, Austin L, Byrne E: LIF (AM424), a promising growth factor for the treatment of ALS. J Neurol Sci 1998;160(suppl 1):106-113.

40 Pennica D, Arce V, Swanson TA, Vejsada R, Pollock RA, Armanini M, Dudley K, Phillips HS, Rosenthal A, Kato AC, Henderson CE: Cardiotrophin-1, a cytokine present in embryonic muscle, supports long-term survival of spinal motoneurons. Neuron 1996;17:63-74.

41 Bilak MM, Shifrin DA, Corse AM, Bilak SR, Kuncl RW: Neuroprotective utility and neurotrophic action of neurturin in postnatal motor neurons: comparison with GDNF and persephin. Mol Cell Neurosci 1999;13:326-336.

42 Bilak MM, Corse AM, Bilak SR, Lehar M, Tombran-Tink J, Kuncl RW: Pigment epithelium-derived factor protects motor neurons from chronic glutamate-mediated neurodegeneration. J Neuropathol Exp Neurol 1999;58: 719-728. 
43 Oosthuyse B, Moons L, Storkebaum E, Beck H, Nuyens D, Brusselmans K, Van Dorpe J, Hellings $\mathrm{P}$, Gorselink M, Heymans S, Theilmeier G, Dewerchin M, Laudenbach V, Vermylen P, Raat H, Acker T, Vleminckx V, Van Den Bosch L, Cashman N, Fujisawa H, Drost MR, Sciot R, Bruyninckx F, Hicklin DJ, Ince C, Gressens P, Lupu F, Plate KH, Robberecht W, Herbert JM, Collen D, Carmeliet P: Deletion of the hypoxia-response element in the vascular endothelial growth factor promoter causes motor neuron degeneration. Nat Genet 2001;28: 131-138.

-44 Askanas V: Neurotrophic factors and amyotrophic lateral sclerosis. Adv Neurol 1995;68: 241-244.

45 Davies AM: Paracrine and autocrine actions of neurotrophic factors. Neurochem Res 1996;21: 749-753.

-46 Mufson EJ, Kroin JS, Sendera TJ, Sobreviela $\mathrm{T}$ : Distribution and retrograde transport of trophic factors in the central nervous system Functional implications for the treatment of neurodegenerative diseases. Prog Neurobiol 1999;57:451-484.

-47 Yan Q, Matheson C, Lopez OT: In vivo neurotrophic effects of GDNF on neonatal and adult facial motor neurons. Nature 1995;373:341344.

-48 Yan Q, Elliott JL, Matheson C, Sun J, Zhang L, $\mathrm{Mu}$ X, Rex KL, Snider WD: Influences of neurotrophins on mammalian motoneurons in vivo. J Neurobiol 1993;24:1555-1577.

-49 Rind HB, von Bartheld CS: Anterograde axonal transport of internalized GDNF in sensory and motor neurons. Neuroreport 2002;13:659664.

-50 Von Bartheld CS, Wang X, Butowt R: Anterograde axonal transport, transcytosis, and recycling of neurotrophic factors: The concept of trophic currencies in neural networks. Mo Neurobiol 2001;24:1-28.

$\checkmark 51$ Adem A, Ekblom J, Gillberg PG: Growth factor receptors in amyotrophic lateral sclerosis. Mol Neurobiol 1994;9:225-231.

52 Duberley RM, Johnson IP, Martin JE, Anand P: RET-like immunostaining of spinal motoneurons in amyotrophic lateral sclerosis. Brain Res 1998;789:351-354.

53 Mitsuma N, Yamamoto M, Li M, Ito Y, Mitsuma T, Mutoh T, Takahashi M, Sobue G: Expression of GDNF receptor (RET and GDNFR- $\alpha$ ) mRNAs in the spinal cord of patients with amyotrophic lateral sclerosis. Brain Res 1999;820:77-85.

D54 Mutoh T, Sobue G, Hamano T, Kuriyama M, Hirayama M, Yamamoto M, Mitsuma T: Decreased phosphorylation levels of TrkB neurotrophin receptor in the spinal cords from patients with amyotrophic lateral sclerosis. Neurochem Res 2000;25:239-245.

$\checkmark 55$ Kushner PD, Stephenson DT, Wright S: Reactive astrogliosis is widespread in the subcortica white matter of amyotrophic lateral sclerosis brain. J Neuropathol Exp Neurol 1991;50:263277.
6 Schiffer D, Cordera S, Cavalla P, Migheli A: Reactive astrogliosis of the spinal cord in amyotrophic lateral sclerosis. J Neurol Sci 1996;139(suppl):27-33.

57 Ekblom J, Jossan SS, Bergstrom M, Oreland L, Walum E, Aquilonius SM: Monoamine oxidase-B in astrocytes. Glia 1993;8:122-132.

58 Aquilonius SM, Jossan SS, Ekblom JG, Askmark H, Gillberg PG: Increased binding of ${ }^{3} \mathrm{H}-$ $L$-deprenyl in spinal cords from patients with amyotrophic lateral sclerosis as demonstrated by autoradiography. J Neural Transm Gen Sect 1992;89:111-122.

59 Koyama Y, Tsujikawa K, Matsuda T, Baba A: Endothelin-1 stimulates glial cell line-derived neurotrophic factor expression in cultured rat astrocytes. Biochem Biophys Res Commun 2003;303:1101-1105.

60 Madiai F, Hussain SR, Goettl VM, Burry RW, Stephens RL Jr, Hackshaw KV: Upregulation of FGF-2 in reactive spinal cord astrocytes following unilateral lumbar spinal nerve ligation. Exp Brain Res 2003;148:366-376.

61 Rudge JS, Pasnikowski EM, Holst P, Lindsay $\mathrm{RM}$ : Changes in neurotrophic factor expression and receptor activation following exposure of hippocampal neuron/astrocyte cocultures to kainic acid. J Neurosci 1995; 15:6856-6867.

62 Batchelor PE, Liberatore GT, Wong JY, Porritt MJ, Frerichs F, Donnan GA, Howells DW: Activated macrophages and microglia induce dopaminergic sprouting in the injured striatum and express brain-derived neurotrophic factor and glial cell line-derived neurotrophic factor. $\mathrm{J}$ Neurosci 1999;19:1708-1716.

63 Hall ED, Oostveen JA, Gurney ME: Relationship of microglial and astrocytic activation to disease onset and progression in a transgenic model of familial ALS. Glia 1998;23:249-256.

64 Levine JB, Kong J, Nadler M, Xu Z: Astrocytes interact intimately with degenerating motor neurons in mouse amyotrophic lateral sclerosis. Glia 1999;28:215-224.

65 Howland DS, Liu J, She Y, Goad B, Maragakis NJ, Kim B, Erickson J, Kulik J, DeVito L, Psaltis G, DeGennaro LJ, Cleveland DW, Rothstein JD: Focal loss of the glutamate transporter EAAT2 in a transgenic rat model of SOD1 mutant-mediated amyotrophic lateral sclerosis. Proc Natl Acad Sci USA 2002;99:16041609.

66 Nagai M, Aoki M, Miyoshi I, Kato M, Pasinelli P, Kasai N, Brown RH Jr, Itoyama Y: Rats expressing human cytosolic copper-zinc superoxide dismutase transgenes with amyotrophic lateral sclerosis: Associated mutations develop motor neuron disease. J Neurosci 2001;21: 9246-9254.

67 Cohen S, Levi-Montalcini R, Hamburger V: A nerve growth-stimulating factor isolated from sarcomas 37 and 180. Proc Natl Acad Sci USA 1954;40:1014-1018.

68 Hamburger V, Levi-Montalcini R: Proliferation, differentiation and degeneration in the spinal ganglia of the chick embryo under normal and experimental conditions. J Exp Zool 1949;111:457-502.
69 Levi-Montalcini R, Hamburger V: Selective growth stimulating effects of sarcoma on the sensory and sympathetic system of the chick embryo. J Exp Zool 1951;116:321-362.

70 Lindsay RM: Trophic protection of motor neurons: Clinical potential in motor neuron diseases. J Neurol 1994;242:S8-11.

71 Anand P, Parrett A, Martin J, Zeman S, Foley P, Swash M, Leigh PN, Cedarbaum JM, Lindsay RM, Williams-Chestnut RE: Regional changes of ciliary neurotrophic factor and nerve growth factor levels in post-mortem spinal cord and cerebral cortex from patients with motor disease. Nat Med 1995;1:168-172.

72 Barde YA, Edgar D, Thoenen H: Purification of a new neurotrophic factor from mammalian brain. EMBO J 1982;1:549-553.

73 Henderson CE, Camu W, Mettling C, Gouin A, Poulsen K, Karihaloo M, Rullamas J, Evans T, McMahon SB, Armanini MP: Neurotrophins promote motor neuron survival and are present in embryonic limb bud. Nature 1993;363:266270.

74 Clatterbuck RE, Price DL, Koliatsos VE: Further characterization of the effects of brainderived neurotrophic factor and ciliary neurotrophic factor on axotomized neonatal and adult mammalian motor neurons. J Comp Neurol 1994;342:45-56.

75 Koliatsos VE, Clatterbuck RE, Winslow JW, Cayouette MH, Price DL: Evidence that brainderived neurotrophic factor is a trophic factor for motor neurons in vivo. Neuron 1993;10: 359-367.

76 Sendtner M, Holtmann B, Kolbeck R, Thoenen $\mathrm{H}$, Barde YA: Brain-derived neurotrophic factor prevents the death of motoneurons in newborn rats after nerve section. Nature 1992;360: 757-759.

77 Yan Q, Matheson C, Lopez OT, Miller JA: The biological responses of axotomized adult motoneurons to brain-derived neurotrophic factor. J Neurosci 1994; 14:5281-5291.

78 Oppenheim RW, Yin QW, Prevette D, Yan Q: Brain-derived neurotrophic factor rescues developing avian motoneurons from cell death. Nature 1992;360:755-757.

79 Kawamoto Y, Nakamura S, Akiguchi I, Kimura $\mathrm{J}$ : Immunohistochemical localization of brain-derived neurotrophic factor in the spinal cords of amyotrophic lateral sclerosis and nonamyotrophic lateral sclerosis patients. J Neuropathol Exp Neurol 1998;57:822-830.

80 Yamamoto M, Mitsuma N, Ito Y, Hattori N, Nagamatsu M, Li M, Mitsuma T, Sobue G: Expression of glial cell line-derived neurotrophic factor and GDNFR- $\alpha$ mRNAs in human peripheral neuropathies. Brain Res 1998;809: 175-181.

81 The BDNF Study Group (Phase III): A controlled trial of recombinant methionyl human BDNF in ALS. Neurology 1999;52:14271433.

82 Apfel SC: Neurotrophic factor therapy - Prospects and problems. Clin Chem Lab Med 2001; 39:351-355. 
83 Ochs G, Penn RD, York M, Giess R, Beck M, Tonn J, Haigh J, Malta E, Traub M, Sendtner M, Toyka KV: A phase I/II trial of recombinant methionyl human brain derived neurotrophic factor administered by intrathecal infusion to patients with amyotrophic lateral sclerosis. Amyotroph Lateral Scler Other Motor Neuron Disord 2000;1:201-206.

-84 Ernfors P, Persson H: Developmentally regulated expression of HDNF/NT-3 mRNA in rat spinal cord motoneurons and expression of BDNF mRNA in embryonic dorsal root ganglion. Eur J Neurosci 1991;3:953-961.

-85 Hallbook F, Ibanez CF, Ebendal T, Persson H: Cellular localization of brain-derived neurotrophic factor and neurotrophin-3 mRNA expression in the early chicken embryo. Eur J Neurosci 1993;5:1-14.

-86 Duberley RM, Johnson IP, Anand P, Leigh PN, Cairns NJ: Immunocytochemical studies of neurotrophins in cerebral motor cortex in amyotrophic lateral sclerosis. Brain Res 1997 763:259-263.

87 Duberley RM, Johnson IP, Anand P, Leigh PN, Cairns NJ: Neurotrophin-3-like immunoreactivity and Trk $\mathrm{C}$ expression in human spinal motoneurones in amyotrophic lateral sclerosis. J Neurol Sci 1997;148:33-40.

$>88$ Hallbook F, Ibanez CF, Persson H: Evolutionary studies of the nerve growth factor family reveal a novel member abundantly expressed in Xenopus ovary. Neuron 1991;6:845-858.

89 Mitsumoto H, Ikeda K, Klinkosz B, Cedarbaum JM, Wong V, Lindsay RM: Arrest of motor neuron disease in wobbler mice cotreated with CNTF and BDNF. Science 1994; 265:1107-1110.

-90 Mitsumoto H, Ikeda K, Holmlund T, Greene T, Cedarbaum JM, Wong V, Lindsay RM: The effects of ciliary neurotrophic factor on motor dysfunction in wobbler mouse motor neuron disease. Ann Neurol 1994;36:142-148.

-91 Sagot Y, Tan SA, Baetge E, Schmalbruch H, Kato AC, Aebischer P: Polymer encapsulated cell lines genetically engineered to release ciliary neurotrophic factor can slow down progressive motor neuronopathy in the mouse. Eur J Neurosci 1995;7:1313-1322.

-92 Sendtner M, Schmalbruch H, Stockli KA, Carroll P, Kreutzberg GW, Thoenen H: Ciliary neurotrophic factor prevents degeneration of motor neurons in mouse mutant progressive motor neuronopathy. Nature 1992;358:502-504.

-93 Penn RD, Kroin JS, York MM, Cedarbaum JM: Intrathecal ciliary neurotrophic factor delivery for treatment of amyotrophic lateral sclerosis (phase I trial). Neurosurgery 1997;40:9499.

-94 Duberley RM, Johnson IP, Anand P, Swash M, Martin J, Leigh PN, Zeman S: Ciliary neurotrophic factor receptor expression in spinal cord and motor cortex in amyotrophic lateral sclerosis. J Neurol Sci 1995;129(suppl):109_ 113.

$\$ 95$ Schorr M, Zhou L, Schwechheimer K: Expression of ciliary neurotrophic factor is maintained in spinal motor neurons of amyotrophic lateral sclerosis. J Neurol Sci 1996;140:117122.
96 Ono S, Imai T, Shimizu N, Nakagawa H, Hu $\mathrm{J}$ : Ciliary neurotropic factor in skin biopsies of patients with amyotrophic lateral sclerosis. Lancet 1998;352:958-959.

97 Metcalf D: The leukemia inhibitory factor. Int J Cell Cloning 1991;9:95-108.

$\checkmark 98$ Martinou JC, Martinou I, Kato AC: Cholinergic differentiation factor (CDF/LIF) promotes survival of isolated rat embryonic motoneurons in vitro. Neuron 1992;8:737-744.

99 Cheema SS, Richards LJ, Murphy M, Bartlett PF: Leukaemia inhibitory factor rescues motoneurones from axotomy-induced cell death. Neuroreport 1994;5:989-992.

$100 \mathrm{Hu}$ J, Imai T, Shimizu N, Nakagawa H, Ono $\mathrm{S}$ : Expression of leukaemia inhibitory factor in skin of patients with amyotrophic lateral sclerosis. Lancet 1999;353:2126-2127.

101 Oppenheim RW, Wiese S, Prevette D, Armanini M, Wang S, Houenou LJ, Holtmann B, Gotz R, Pennica D, Sendtner M: Cardiotrophin-1, a muscle-derived cytokine, is required for the survival of subpopulations of developing motoneurons. J Neurosci 2001; 21:1283-1291.

102 Sekizawa T, Openshaw H, Ohbo K, Sugamura K, Itoyama Y, Niland JC: Cerebrospinal fluid interleukin-6 in amyotrophic lateral sclerosis: Immunological parameter and comparison with inflammatory and non-inflammatory central nervous system diseases. J Neurol Sci 1998;154:194-199.

103 Krieger C, Perry TL, Ziltener HJ: Amyotrophic lateral sclerosis: interleukin-6 levels in cerebrospinal fluid. Can J Neurol Sci 1992; 19:357-359.

104 Ono S, Hu J, Shimizu N, Imai T, Nakagawa $\mathrm{H}$ : Increased interleukin- 6 of skin and serum in amyotrophic lateral sclerosis. J Neurol Sci 2001;187:27-34.

105 Henderson CE, Phillips HS, Pollock RA, Davies AM, Lemeulle C, Armanini M, Simmons L, Moffet B, Vandlen RA, Simpson LC: GDNF: A potent survival factor for motoneurons present in peripheral nerve and muscle. Science 1994;266:1062-1064.

106 Saarma M, Sariola H: Other neurotrophic factors: Glial cell line-derived neurotrophic factor. Microsc Res Tech 1999;45:292-302.

107 Yamamoto M, Sobue G, Yamamoto K, Terao $\mathrm{S}$, Mitsuma T: Expression of glial cell linederived growth factor mRNA in the spinal cord and muscle in amyotrophic lateral sclerosis. Neurosci Lett 1996;204:117-120.

108 Lewis ME, Neff NT, Contreras PC, Stong DB, Oppenheim RW, Grebow PE, Vaught JL: Insulin-like growth factor-I: Potential for treatment of motor neuronal disorders. Exp Neurol 1993;124:73-88.

109 Neff NT, Prevette D, Houenou LJ, Lewis ME, Glicksman MA, Yin QW, Oppenheim RW: Insulin-like growth factors: Putative muscle-derived trophic agents that promote motoneuron survival. J Neurobiol 1993;24: 1578-1588.
110 Lai EC, Felice KJ, Festoff BW, Gawel MJ, Gelinas DF, Kratz R, Murphy MF, Natter HM, Norris FH, Rudnicki SA: Effect of recombinant human insulin-like growth factorI on progression of ALS. A placebo-controlled study. The North America ALS/IGF-I Study Group. Neurology 1997;49:1621-1630.

111 Lange DJ, Felice KJ, Festoff BW, Gawel MJ, Gelinas DF, Kratz R, Lai EC, Murphy MF, Natter HM, Norris FH, Rudnicki S: Recombinant human insulin-like growth factor-I in ALS: Description of a double-blind, placebocontrolled study. North American ALS/IGF-I Study Group. Neurology 1996;47:S93-S94.

112 Borasio GD, Robberecht W, Leigh PN, Emile J, Guiloff RJ, Jerusalem F, Silani V, Vos PE, Wokke JH, Dobbins T: A placebo-controlled trial of insulin-like growth factor-I in amyotrophic lateral sclerosis. European ALS/IGF-I Study Group. Neurology 1998;51:583-586.

113 Dore S, Krieger C, Kar S, Quirion R: Distribution and levels of insulin-like growth factor (IGF-I and IGF-II) and insulin receptor binding sites in the spinal cords of amyotrophic lateral sclerosis patients. Brain Res Mol Brain Res 1996;41:128-133.

114 Kerkhoff H, Hassan SM, Troost D, Van Etten RW, Veldman H, Jennekens FG: Insulin-like and fibroblast growth factors in spinal cords, nerve roots and skeletal muscle of human controls and patients with amyotrophic lateral sclerosis. Acta Neuropathol (Berl) 1994;87: 411-421.

115 Adem A, Ekblom J, Gillberg PG, Jossan SS, Hoog A, Winblad B, Aquilonius SM, Wang LH, Sara V: Insulin-like growth factor-1 receptors in human spinal cord: changes in amyotrophic lateral sclerosis. J Neural Transm Gen Sect 1994;97:73-84.

116 Braunstein GD, Reviczky AL: Serum insulinlike growth factor-I levels in amyotrophic lateral sclerosis. J Neurol Neurosurg Psychiatry 1987;50:792-794.

117 Stock A, Kuzis K, Woodward WR, Nishi R, Eckenstein FP: Localization of acidic fibroblast growth factor in specific subcortical neuronal populations. J Neurosci 1992;12:46884700.

118 Tourbah A, Oliver L, Jeanny JC, Gumpel M: Acidic fibroblast growth factor is expressed in the neuronal and glial spinal cord cells of adult mice. J Neurosci Res 1991;29:560568

119 Wilcox BJ, Unnerstall JR: Expression of acidic fibroblast growth factor mRNA in the developing and adult rat brain. Neuron 1991; 6:397-409.

120 Tooyama I: Fibroblast growth factors in neurodegenerative disorders (in Japanese). Rinsho Shinkeigaku 1993;33:1270-1274.

121 Cuevas P, Carceller F, Gimenez-Gallego G: Acidic fibroblast growth factor prevents postaxotomy neuronal death of the newborn rat facial nerve. Neurosci Lett 1995;197:183-186.

122 Kuzis K, Coffin JD, Eckenstein FP: Time course and age dependence of motor neuron death following facial nerve crush injury: Role of fibroblast growth factor. Exp Neurol 1999;157:77-87. 
123 Kage M, Yang Q, Sato H, Matsumoto S, Kaji R, Akiguchi I, Kimura H, Tooyama I: Acidic fibroblast growth factor (FGF-1) in the anterior horn cells of ALS and control cases. Neuroreport 2001;12:3799-3803.

124 Johansson A, Larsson A, Nygren I, Blennow $\mathrm{K}$, Askmark H: Increased serum and cerebrospinal fluid FGF-2 levels in amyotrophic lateral sclerosis. Neuroreport 2003;14:18671869.

-125 Funakoshi H, Nakamura T: Hepatocyte growth factor: From diagnosis to clinical applications. Clin Chim Acta 2003;327:1-23.

126 Maina F, Klein R: Hepatocyte growth factor, a versatile signal for developing neurons. Nat Neurosci 1999;2:213-217.

127 Yamamoto Y, Livet J, Pollock RA, Garces A, Arce V, deLapeyriere O, Henderson CE: Hepatocyte growth factor $(\mathrm{HGF} / \mathrm{SF})$ is a musclederived survival factor for a subpopulation of embryonic motoneurons. Development 1997; 124:2903-2913.

128 Kato S, Funakoshi H, Nakamura T, Kato M, Nakano I, Hirano A, Ohama E: Expression of hepatocyte growth factor and c-Met in the anterior horn cells of the spinal cord in the patients with amyotrophic lateral sclerosis (ALS): Immunohistochemical studies on sporadic ALS and familial ALS with superoxide dismutase-1 gene mutation. Acta Neuropathol (Berl) 2003;106:112-120.

129 Houenou LJ, D’Costa AP, Li L, Turgeon VL, Enyadike C, Alberdi E, Becerra SP: Pigment epithelium-derived factor promotes the survival and differentiation of developing spinal motor neurons. J Comp Neurol 1999;412. 506-514.

130 Lambrechts D, Storkebaum E, Morimoto M, Del-Favero J, Desmet F, Marklund SL, Wyns $\mathrm{S}$, Thijs V, Andersson J, van Marion I, AlChalabi A, Bornes S, Musson R, Hansen V, Beckman L, Adolfsson R, Pall HS, Prats H, Vermeire S, Rutgeerts P, Katayama S, Awata T, Leigh N, Lang-Lazdunski L, Dewerchin M, Shaw C, Moons L, Vlietinck R, Morrison KE, Robberecht W, Van Broeckhoven C, Collen $\mathrm{D}$, Andersen PM, Carmeliet P.: VEGF is a modifier of amyotrophic lateral sclerosis in mice and humans and protects motoneurons against ischemic death. Nat Genet 2003;34: 383-394.

131 Stockhammer G, Poewe W, Burgstaller S, Deisenhammer F, Muigg A, Kiechl S, Schmutzhard E, Maier H, Felber S, Schumacher P, Gunsilius E, Gastl G: Vascular endothelial growth factor in CSF: A biological marker for carcinomatous meningitis. Neurology 2000;54:1670-1676.

$>132$ Duong F, Fournier J, Keane PE, Guenet JL, Soubrie P, Warter JM, Borg J, Poindron P: The effect of the nonpeptide neurotrophic compound SR 57746A on the progression of the disease state of the pmn mouse. Br J Pharmacol 1998; 124:811-817.

133 Duong FH, Warter JM, Poindron P, Passilly P: Effect of the nonpeptide neurotrophic compound SR 57746A on the phenotypic survival of purified mouse motoneurons. $\mathrm{Br} \mathrm{J}$ Pharmacol 1999;128:1385-1392.
134 Iwasaki Y, Shiojima T, Kinoshita M, Ikeda K: SR57746A: A survival factor for motor neurons in vivo. J Neurol Sci 1998;160(suppl 1):92-96.

135 Elliott JL: Experimental models of amyotrophic lateral sclerosis. Neurobiol Dis 1999;6: 310-320.

136 Ikeda K, Iwasaki Y, Tagaya N, Shiojima T, Kobayashi T, Kinoshita M: Neuroprotective effect of basic fibroblast growth factor on wobbler mouse motor neuron disease. Neurol Res 1995;17:445-448.

137 Ikeda K, Klinkosz B, Greene T, Cedarbaum JM, Wong V, Lindsay RM, Mitsumoto $\mathrm{H}$ : Effects of brain-derived neurotrophic factor on motor dysfunction in wobbler mouse motor neuron disease. Ann Neurol 1995;37:505511.

138 Ikeda K, Wong V, Holmlund TH, Greene T, Cedarbaum JM, Lindsay RM, Mitsumoto H: Histometric effects of ciliary neurotrophic factor in wobbler mouse motor neuron disease. Ann Neurol 1995;37:47-54.

139 Ishiyama T, Klinkosz B, Pioro EP, Mitsumoto $\mathrm{H}:$ Genetic transfer of the wobbler gene to a C57BL/6J $\times$ NZB hybrid stock: Natural history of the motor neuron disease and response to CNTF and BDNF cotreatment. Exp Neurol 1997;148:247-255.

140 Mitsumoto H, Klinkosz B, Pioro EP, Tsuzaka $\mathrm{K}$, Ishiyama T, O'Leary RM, Pennica D: Effects of cardiotrophin-1 in a mouse motor neuron disease. Muscle Nerve 2001;24:769777.

141 Bordet T, Schmalbruch H, Pettmann B, Hagege A, Castelnau-Ptakhine L, Kahn A, Haase G: Adenoviral cardiotrophin-1 gene transfer protects pmn mice from progressive motor neuronopathy. J Clin Invest 1999;104:10771085.

142 Manabe Y, Nagano I, Gazi MS, Murakami T, Shiote M, Shoji M, Kitagawa H, Abe K: Glial cell line-derived neurotrophic factor protein prevents motor neuron loss of transgenic model mice for amyotrophic lateral sclerosis. Neurol Res 2003;25:195-200.

143 Tsuzaka K, Ishiyama T, Pioro EP, Mitsumoto $\mathrm{H}$ : Role of brain-derived neurotrophic factor in wobbler mouse motor neuron disease. Muscle Nerve 2001;24:474-480.

144 Azari MF, Galle A, Lopes EC, Kurek J, Cheema SS: Leukemia inhibitory factor by systemic administration rescues spinal motor neurons in the SOD1 G93A murine model of familial amyotrophic lateral sclerosis. Brain Res 2001;922:144-147.

145 Ikeda K, Iwasaki Y, Shiojima T, Kinoshita M: Neuroprotective effect of various cytokines on developing spinal motoneurons following axotomy. J Neurol Sci 1996;135:109113.

146 Acsadi G, Anguelov RA, Yang H, Toth G, Thomas R, Jani A, Wang Y, Ianakova E, Mohammad S, Lewis RA, Shy ME: Increased survival and function of SOD1 mice after glial cell-derived neurotrophic factor gene therapy. Hum Gene Ther 2002;13:10471059.
147 Mizuta I, Ohta M, Ohta K, Nishimura M, Mizuta E, Kuno S: Riluzole stimulates nerve growth factor, brain-derived neurotrophic factor and glial cell line-derived neurotrophic factor synthesis in cultured mouse astrocytes. Neurosci Lett 2001;310:117-120.

148 Bilak MM, Corse AM, Kuncl RW: Additivity and potentiation of IGF-I and GDNF in the complete rescue of postnatal motor neurons. Amyotroph Lateral Scler Other Motor Neuron Disord 2001;2:83-91.

149 Haase G, Kennel P, Pettmann B, Vigne E, Akli S, Revah F, Schmalbruch H, Kahn A: Gene therapy of murine motor neuron disease using adenoviral vectors for neurotrophic factors. Nat Med 1997;3:429-436.

150 Yamamoto M, Kobayashi Y, Li M, Niwa H, Mitsuma N, Ito Y, Muramatsu T, Sobue G: In vivo gene electroporation of glial cell linederived neurotrophic factor into skeletal muscle of SOD1 mutant mice. Neurochem Res 2001;26:1201-1207.

151 Albeck DS, Hoffer BJ, Quissell D, Sanders LA, Zerbe G, Granholm AC: A non-invasive transport system for GDNF across the bloodbrain barrier. Neuroreport 1997;8:22932298.

152 Tenenbaum L, Chtarto A, Lehtonen E, Velu T, Brotchi J, Levivier M: Recombinant adeno-associated virus-mediated gene delivery to the central nervous system. J Gene Med 2004; 6(suppl 1):212-222.

153 Kaspar BK, Llado J, Sherkat N, Rothstein JD, Gage FH: Retrograde viral delivery of IGF-1 prolongs survival in a mouse ALS model. Science 2003;301:839-842.

154 Baloh RH, Tansey MG, Lampe PA, Fahrner TJ, Enomoto H, Simburger KS, Leitner ML, Araki T, Johnson EM Jr, Milbrandt J: Artemin, a novel member of the GDNF ligand family, supports peripheral and central neurons and signals through the GFR $\alpha 3$-RET receptor complex. Neuron 1998;21:12911302.

155 Milbrandt J, de Sauvage FJ, Fahrner TJ, Baloh RH, Leitner ML, Tansey MG, Lampe PA, Heuckeroth RO, Kotzbauer PT, Simburger KS, Golden JP, Davies JA, Vejsada R, Kato AC, Hynes M, Sherman D, Nishimura M, Wang LC, Vandlen R, Moffat B, Klein RD, Poulsen K, Gray C, Garces A, Johnson EM Jr: Persephin, a novel neurotrophic factor related to GDNF and neurturin. Neuron 1998;20: 245-253.

156 Kotzbauer PT, Lampe PA, Heuckeroth RO, Golden JP, Creedon DJ, Johnson EM Jr, Milbrandt J: Neurturin, a relative of glial-cellline-derived neurotrophic factor. Nature 1996;384:467-470.

157 Sorenson EJ, Stalker AP, Kurland LT, Windebank AJ: Amyotrophic lateral sclerosis in Olmsted County, Minnesota, 1925-1998. Neurology 2002;59:280-282. 